\title{
Integration of Multiple Uses to Create a Central Place for the Community: An Approach towards a Sustainable Town Centre Development at Baze Shilinda, Rajshahi
}

\author{
Abdulla - Al Kafy,2*, Nahidul Islam², Sabrina Sharmin², Farhana Mahzabin², Mahmud Arafat ${ }^{2}$, Sumita Roy ${ }^{2}$ and Lamia \\ Ferdous $^{2}$ \\ ${ }^{1} B$ \& F Engineering \& Construction Ltd., Gulshan - 2, Dhaka, Bangladesh \\ ${ }^{2}$ Department of Urban \& Regional Planning, Rajshahi University of Engineering \& Technology (RUET), Rajshahi, Bangladesh
}

Received: 眥 May 24, 2018; Published: 䟧 June 19, 2018

*Corresponding author: Abdulla Al Kafy, Research Consultant, Center for Environmental and Geographic Information Services, House No-7, Road no-5, Kaderabad Housing, Mohammadpur, Dhaka- 1207, Bangladesh. Tel: +8801771411138, Email: sunnykafy@gmail.com

\begin{abstract}
Town centre is the social hub of the town in which the central services of the highest order are found. For being one of the fast growing cities in Bangladesh, Rajshahi needs sustainable town centre with the integration of administrative, commercial, recreational, residential and industrial activities which will ensure smart and sustainable urban growth of the city. In this context, Baze Shilinda at Paba Upazila in Rajshahi district has been selected for the development of town centre. The study aims to develop a sustainable Town Centre by ensuring better urban design and integration of multiple functions. The proposed Town Centre has also been designed as a flexible multiple use district of vertical mixed-use buildings that brings retail, office, civic, recreational, and residential uses together and developed social connectivity throughout different proposed zones. The complete town centre design has been accomplished with the help of Arc GIS 10.3 software in which Create Fishnet tool has been used for plotting in different zones. All the proposed utility facilities have been estimated using planning standard, appropriate land use distribution and facility provision. The proposed town centre design will fulfil the need of a fast growing community which ensures use of multiple functions to maximize the use of resources and generates activity and economic flow to any cities in Bangladesh. The study can be a guideline for any future town centre development because of its uniqueness and sustainability in its design.
\end{abstract}

Keywords: Urban Growth; Sustainable; Economic flow; Multiple functions; Arc GIS; Urban design

\section{Introduction}

Town centers are complex places that serve a wide range of people and purposes [1]. Town center functions as an administrative center, business center, entertainment and cultural center, a place for meeting and service industries [2]. Traditionally, housing is also a component of a Town Center, either above commercial space or adjacent to it and finally, these functions are integrated in a manner that facilitates social interaction [3]. These multipurpose uses generate activity to the place and make the place a central place for the whole community. Active mixed use can create a vibrant town center [4]. A town center is an enduring, walk able, and integrated open-air, multiuse development that is organized around a clearly identifiable and energized public realm where citizens can gather and strengthen their community bonds [5,6]. It is anchored by retail, dining, and leisure uses, as well as by vertical or horizontal residential uses [7]. The primary function of town centres is service provision for a local and non-local population [8]. Rajshahi (historically Rampur Boalia; nicknamed Silk City) is a metropolitan city in Bangladesh and a major urban, commercial and educational center of North Bengal. But there is only one town center at Saheeb Bazar which cannot fulfill the demand of the people and also cannot equally provide all facilities to the surrounding area. It is very tough for a single town center to cover the entire Rajshahi city 
with utility services because of the growing population of the city [9]. Development of any town center in Rajshahi City will go a long to serve this growing people. At the same time a town center will generate more economic activity to the city and consequence will be the betterment of the city. So designing a town center is a need of Rajshahi City in its present condition and this study fulfills the need in this context.

Rajshahi Metropolitan Development Plan (2004) includes three town centers in the city one of them is at Baze Shilinda. There cannot be any town center within three kilometers of another town center [10]. Baze Shilinda is situated at $3.7 \mathrm{kms}$ from the existing town center at Saheb Bazar. Moreover this place has smooth accessibility from the surroundings, suitable topographic condition and the potentiality to establish as a town center. These all considerations made the researchers to select 'Baze Shilinda' as the study area. The study aims to develop a sustainable Town Centre by ensuring better urban design and integration of multiple functions. Better Urban Design includes vertical mixed-use buildings that bring together retail, office, civic, recreational, and residential uses with a primary focus on retail activity as well as encourage civic elements (i.e. parks and plazas) and institutions to locate in the Town Center. Integration of multiple functions indicates the integration of Transport facilities, public open spaces consisting of parks, plazas, and greenbelts and enhances pedestrian access in the Town Center through development of sidewalks.

\section{Methodology}

\section{Site selection}

Location, transportation and accessibility are key determinants of success and that is why the site selection draw such attention [6]. With the help of SWOT analysis and reconnaissance survey Baze Shilinda, has been selected to be developed as a town center. The reconnaissance survey provides information about the land use, physical structures, natural resources and the surroundings. The collected primary data helped to make a SWOT (Strength, Weakness, Opportunity, and Threat) analysis of the study area. The secondary data (especially Rajshahi Metropolitan Development Plan) also helped in this context. The analysis determined the needs and prospects of the place in designing a town center.

\section{Design and design principles}

According to the necessity, the land use has been distributed. Some preliminary hand drawing has been prepared and the best alternative has been chosen. In this context some considerations include; ensuring better urban design, sustainable transport, livable community, developing the Town Centre as a flexible multiple use district of vertical mixed-use buildings that brings together retail, office, civic, recreational, and residential uses with a primary focus on retail activity, encouraging civic elements, establishing an efficient flow of motor vehicle traffic, enhancing pedestrian access, and providing an integrated system $[7,11,12]$. The estimation of land uses has been prioritized to fulfill the land use demand. The finally selected hand drawing plan has been drawn in Arc GIS software. Create fishnet tool in Arc GIS (Geographic Information System) has been used for designing the Town centre. The final report consists all detailing and a complete reflection of the design proposal (Table 1). On the basis of the information, some models (mainly Garden city and multiple nuclei model) has been chosen for the designing of the Town Centre. Circular and sectoral pattern has been used in the design so that it can provide high density of population. The grids repetitive and expansive nature means it is ideal for growth of cities and town. The design mostly prioritizes ecological protection with a lot of open spaces and no harmful structure. Encouraging people for walking by designing all the facilities within walking distance the design ensures a pedestrian friendly and well accessible transportation network. The design ensured social connectivity by providing community center, outdoor recreation, commercial facilities and education facilities, administration offices, community Park, etc $[3,7,10,12]$. The commercial and other activities will generate employment which will contribute to local economy and a long term economic benefit. Along with providing all utility facilities the design encourages rain water harvesting and energy efficient activity [7]. Thus the design integrates all the facilities along with ensuring flexibility and sustainability.

Table 1: Design standards for community service in acres.

\begin{tabular}{|c|c|c|c|}
\hline \multirow[b]{2}{*}{ Community Services } & \multicolumn{3}{|c|}{ Size of the Population } \\
\hline & $\begin{array}{l}\text { Residential } \\
(62000)\end{array}$ & $\begin{array}{l}\text { Mix Use } \\
(41280)\end{array}$ & $\begin{array}{l}\text { Industrial } \\
(3500)\end{array}$ \\
\hline \multicolumn{4}{|c|}{ Education } \\
\hline Nursery School & 4.96 & 3.2 & - \\
\hline Primary School & 4.96 & 3.2 & - \\
\hline Secondary School and College & 6.2 & 4 & \\
\hline \multicolumn{4}{|c|}{ Health } \\
\hline Small clinic & 2.48 & 1.6 & - \\
\hline Hospital & 2.48 & 1.6 & \\
\hline \multicolumn{4}{|c|}{ Utility \& Community Services } \\
\hline $\begin{array}{l}\text { Utility Community and } \\
\text { Religious Services }\end{array}$ & 2.48 & 1.6 & - \\
\hline \multicolumn{4}{|c|}{ Recreation } \\
\hline Playground & 4.96 & 3.2 & - \\
\hline Park & 7.44 & 4.8 & \\
\hline \multicolumn{4}{|c|}{ Commercial } \\
\hline Corner shop/Market/Bazar & 2.48 & 1.6 & 0.14 \\
\hline \multicolumn{4}{|c|}{ Roads } \\
\hline Residential Roads & 21.08 & 13.6 & 1.19 \\
\hline $\begin{array}{c}\text { Total Area For Community } \\
\text { Facilities }\end{array}$ & 60 Acres & 38 Acres & 1.33 acres \\
\hline
\end{tabular}




\section{Study area profile}

The city of Rajshahi is the divisional headquarters of Rajshahi division as well as the administrative district that bears its name and is one of the six metropolitan cities of Bangladesh. Often referred to as Silk City and Education City, Rajshahi is located at $24.40^{\circ} \mathrm{N} 88.50^{\circ} \mathrm{E}$ and is situated on the northern banks of the river Padma. It consists of nine Upazilas, 14 Pourasavas and seventy one unions. Paba is one of the upazila of Rajshahi. Paba Upazila (Rajshahi district) area $280.42 \mathrm{sq} . \mathrm{km}$, located in between $24^{\circ} 18^{\prime}$ and $24^{\circ} 31^{\prime}$ north latitudes and in between $88^{\circ} 28^{\prime}$ and $88^{\circ} 43^{\prime}$ east longitudes. It is bounded by mohanpur and tanore upazilas on the north, west bengal state of India and charghat upazila on the south, puthia and durgapur (rajshahi) upazilas on the east, godagari upazila on the west. The area selected for town Centre development is a part of paba upazila. The name of the proposed town centre area is Baze Shilinda. It is situated $3.4 \mathrm{~km}$ from "Rajshahi Railway Station", $1.1 \mathrm{~km}$ from "Rajshahi Divisional Stadium", $6.9 \mathrm{~km}$ from "Shah Makhdum Airport", Rajshahi, 3.7km from "Saheb Bazar", $2.8 \mathrm{~km}$ from "New Market ", $1.8 \mathrm{~km}$ from "Bornali Mor" and $1.6 \mathrm{~km}$ from "Rajshahi medical college", Rajshahi. The study area that is the Baze Shilinda is in Paba Union of Rajshahi District (Figure 1).

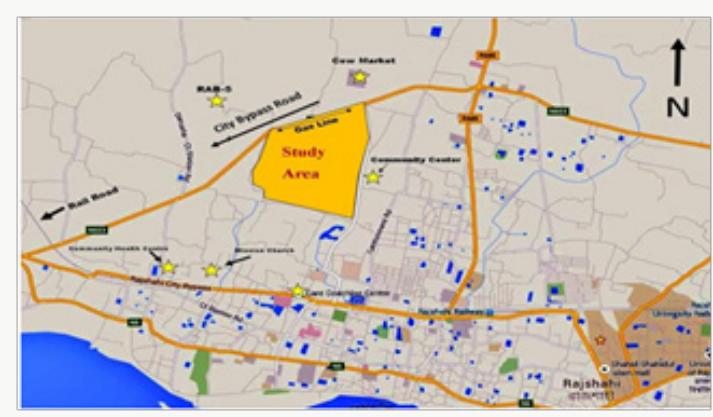

Figure 1: Location of the study area within Paba Upazila.

\section{Results and Discussions}

\section{Proposed town center design}

Zoning is the process of planning for land use by a locality to allocate certain kinds of structure in certain areas. Zoning also includes restrictions in different zoning areas, such as height of buildings, use of green space, density (number of structure of certain area), use of lots, and types of businesses. Zoning is a technique of land use planning as a tool of urban planning used by local governments in most development countries.

For the purpose of these regulations, the planning area of the town is divided into following zones.

a) Core Area.

b) Mixed Use Zone.

c) Civic Zone.

d) Residential Zone. e) Industrial Zone (Light, Medium, Heavy \& Service) (Figure 2 \& 3).

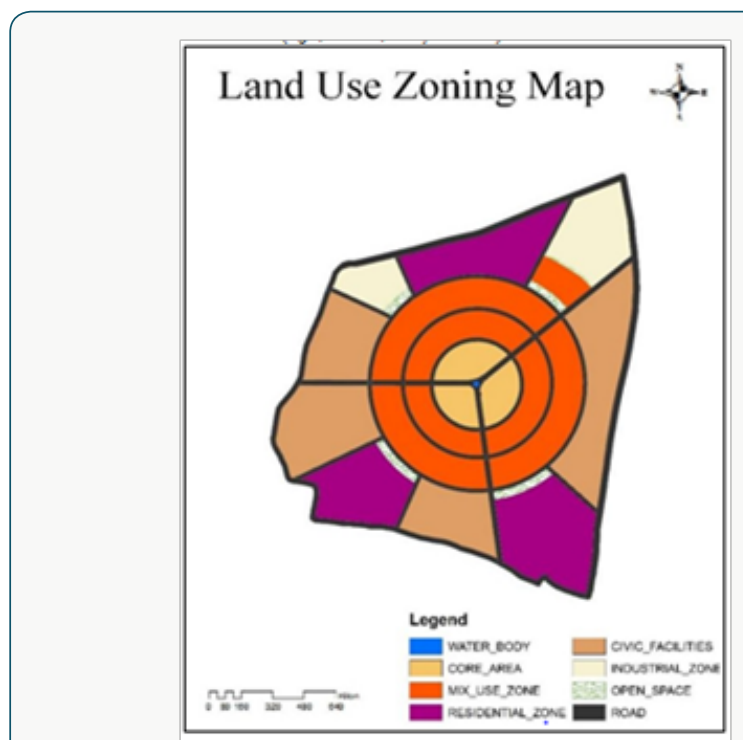

Figure 2: Land Use Map of Proposed Town Center.

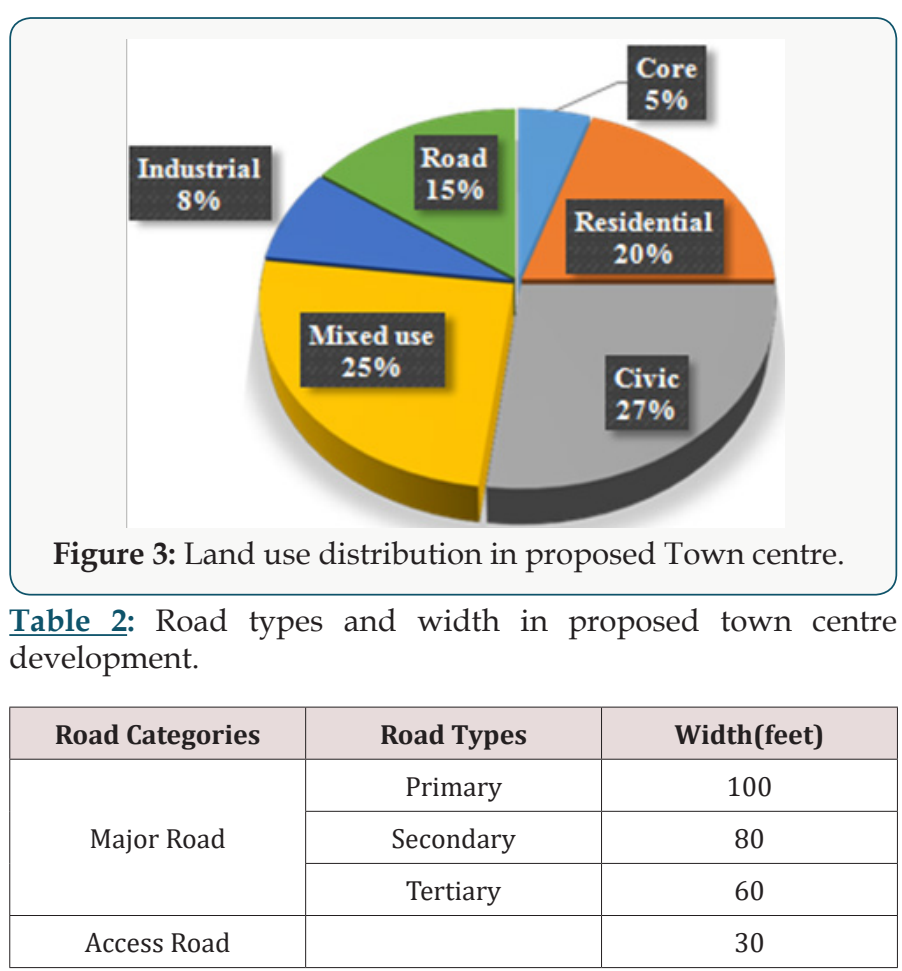

The pie chart shows that a combination of $5 \%$ core area, $15 \%$ road network, $8 \%$ heavy and light industries, $25 \%$ mixed land use, $27 \%$ civic zone and $20 \%$ residential land uses integrate the town center (Table 2). There should be balance between the narrow streets and wide roads in the design to make it attractive (Figure 4). The study combines both major roads and access roads to make the town center well connected and functional. The major roads are of three types; Primary roads (100ft wide), Secondary roads (80ft wide), and Tertiary roads ( $60 \mathrm{ft}$ wide) and the access road is $30 \mathrm{ft}$ wide. The roads are distributed mainly in radial pattern and 
grid iron pattern. A combination of major and access roads create a great road network which connects all the parts of the town center. The road network not only connects the different zones of the town center but also connects the town center with the surrounding land uses.

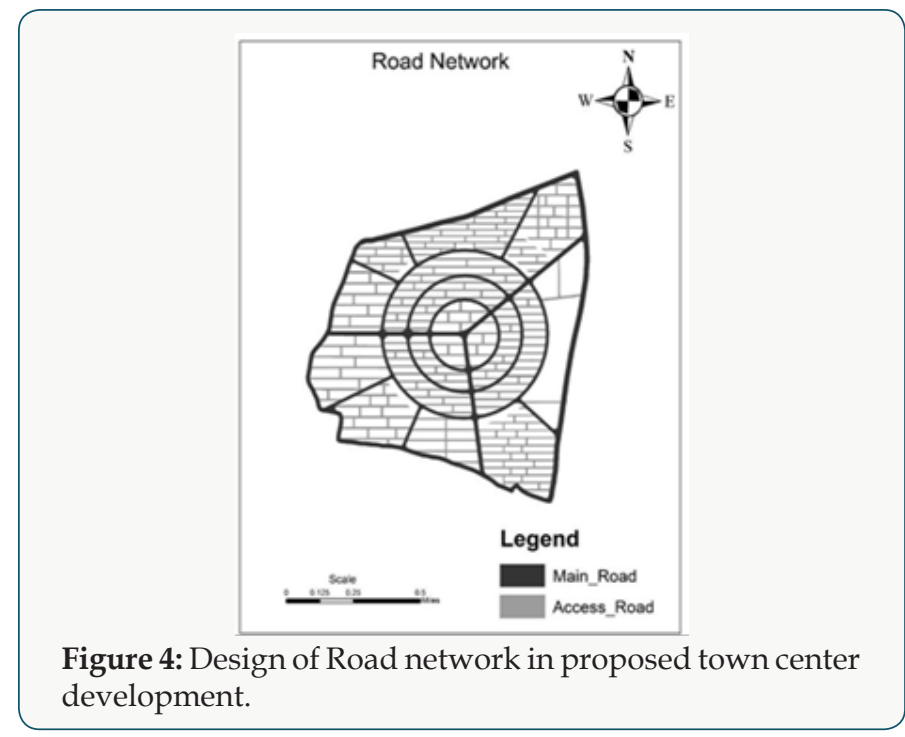

\section{Design description of core area}

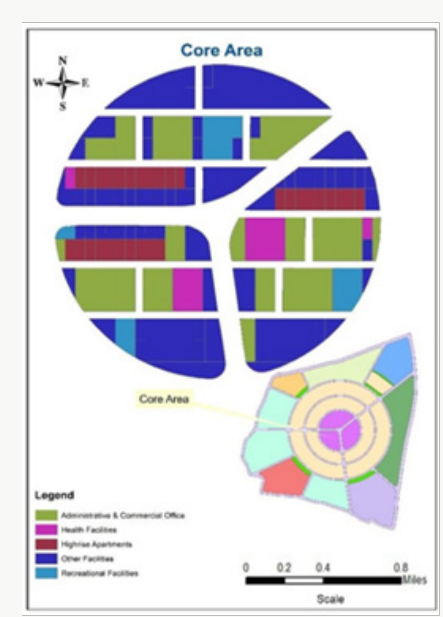

Figure 5: Design of Core area in Proposed Town Center Development.

The Core area of a town is usually a preferred location for international and national Civic and Cultural organizations (Figure 5), government business (civic center), business and Commerce, small scale business/informal sector operators etc. because of the opportunities that it presents. This makes the use of space in such areas highly competitive. Most local and international businesses are headquartered in the Core area. The center should provide examples of the best architectural and urban design practices. The intent is to achieve such intensive civic and cultural, commercial and business activities in the Core zone. To ensure the zone functions efficiently, strict measures will be applied to traffic management, servicing and building design. Aesthetics in the CBD will be enhanced through the development of a network of public open spaces and landscaping as part of the street furniture. This zone permits commercial office development, head offices, banks, transport stations, hospitals \& pharmacies, markets, hotels and restaurants, parking facilities, recreational facilities, major retail stores, community center and prohibits single unit residential development, industrial development and major warehousing (Figure 6). The core area occupies only 5\% of total area among which $40 \%$ commercial, $16 \%$ administrative, $15 \%$ road, 5\% recreational and $24 \%$ are dedicated to other facilities.

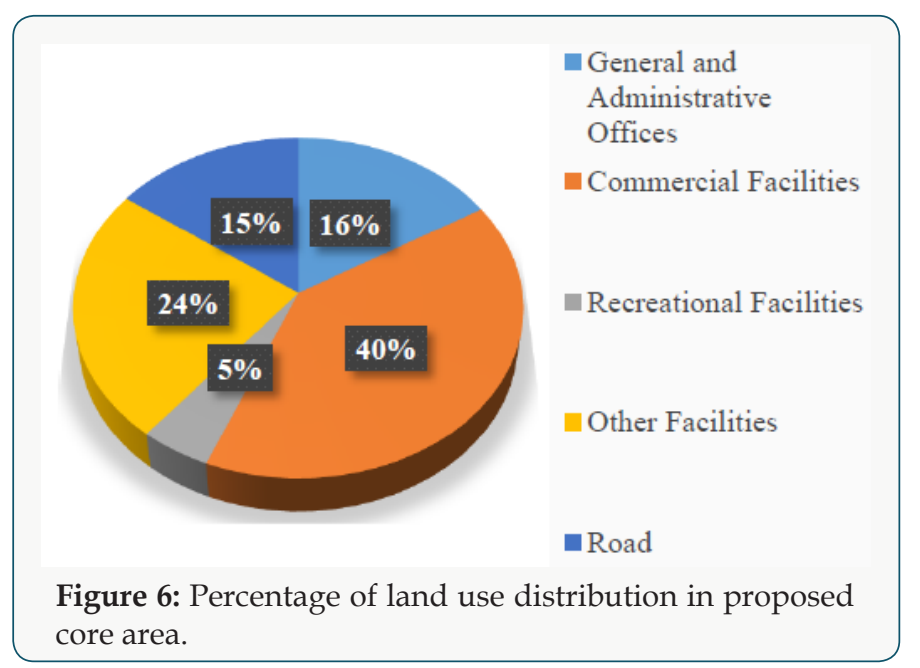

\section{Design description of residential area}

A residential area is a land use in which housing predominates, as opposed to industrial and commercial areas. Housing may vary significantly between, and through, residential areas. These include single-family housing, multi-family residential, or homes. Zoning for residential use may permit some services or work opportunities or may totally exclude business and industry. It may permit high density land use or only permit low density uses. Facilities that are provided are dwellings, hostels including working women and gents' hostels, old age homes, orphanages, places of public worship, schools offering higher primary school courses, public libraries, post offices and telegraph offices. Residential area is classified into Three categories:
a) Middle Class Residential Area
b) High Class Residential Area
c) Low Class Residential Area

Middle class residential area: Land included in a Middle Class Residential zone is intended to provide for a variety of residential uses at net site densities of between 16 and 30 dwelling per hectare. The form of development will comprise a mixture of detached, semidetached (duplex), row (terraced) and compound houses (Figures $7 \& 8$ ). Some small retail development would be permissible in this zone in selected areas, to accommodate the day to day shopping needs of the population. To ensure that an adequate level of amenity is achieved, small areas of public open spaces will be intermixed with the development. Major commercial, 
industrial transportation activities will be excluded from the zone so as to minimize traffic congestion and preserve the residential character of the zone. This zone accommodates 23000 population with 423 no. 4 Katha plots which contains 4 and 5 stories buildings of 3 and 2 units. The middle class residential zone provide its $66 \%$ area for residential purpose and the other portion for the facility of the residents of this zone like education (6\%), recreation (3\%), religious purpose (2\%), health care (25), shops (6\%) and others facilities $(15 \%)$.
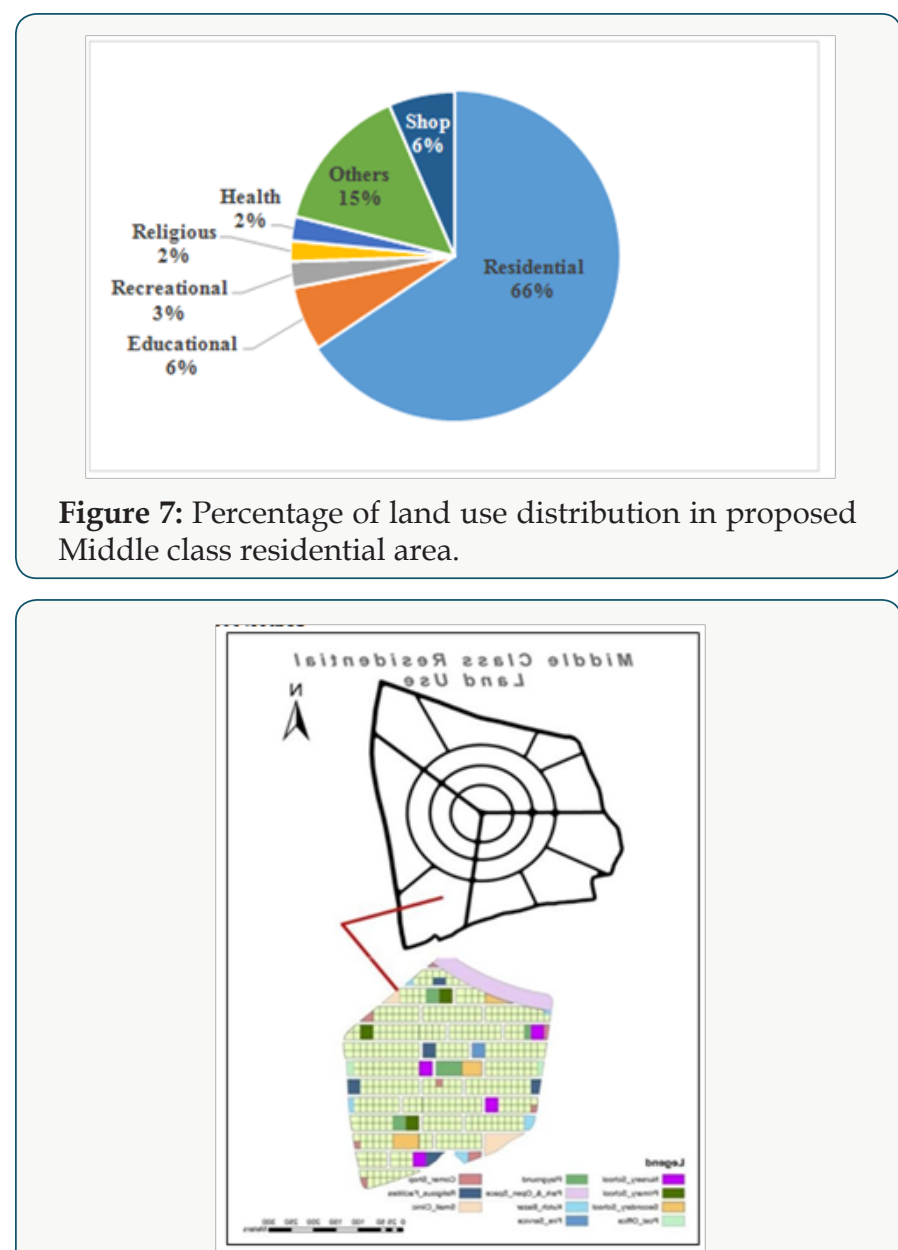

Figure 8: Design of Middle class residential area in Proposed Town Center Development.

Higher class residential area: Land in the High Class Residential Zone is intended to remain as an area for low density residential development, with a housing density of 10-15 dwellings per hectare. Industrial, commercial and mixed land use activities will be excluded from the zone so as to maintain a spacious, environment, free from intrusion by incompatible land use. Land uses like transportation for haulage, commercial Development over $250 \mathrm{~m}^{2}$ and crematorium or cemetery are forbidden in this zone (Figure 9). This zone accommodates 10710 population with 250 no. 5 Katha plots which contains 1 and 6 stories buildings of 1 and 2 units. $79 \%$ area of this zone is mainly for residence purpose of high income people and the other area provides facilities like education $(5 \%)$, recreation $(8 \%)$, religious purpose $(2 \%)$, health care $(1 \%)$, shops (2\%), and other facilities (3\%). The education facilities incorporate nursery schools, primary schools and secondary schools (Figure 10).
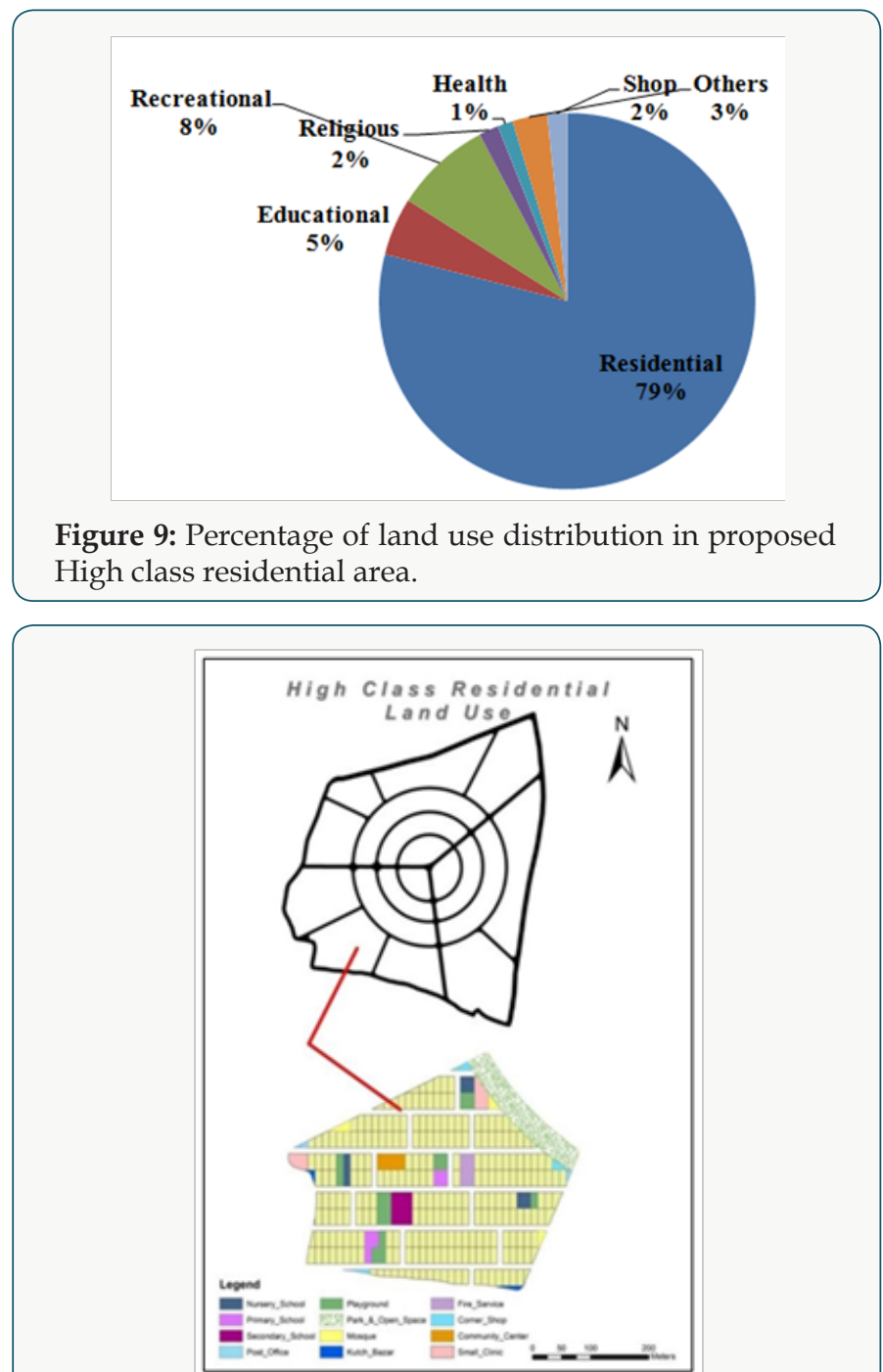

Figure 10: Design of High class residential area in Proposed Town Center Development.

Low class residential area: The chart shows that $61 \%$ area of low class residential zone accommodate 25000 people with a high density. Land in a Low Class Residential Zone is intended for intensive residential development with densities in excess of 30 dwellings per hectare. The minimum plot size on which a development will be approved is $110 \mathrm{~m}^{2}$ but only if adequate provision is made for public open space, roads and footpaths and parking areas. This zone comprises urban low income and informal sector housing areas, which can be upgraded to meet the minimum space requirements. This zone accommodates 25000 population with 400 no. 3 Katha plots which contains 3 and 4 stories buildings of 3 units. This zone allows uses like detached and semidetached housing, row \& compound housing, home business, parks \& playground, places of public worship, clinic, outdoor/indoor recreational facilities, primary and junior high schools, public 
transport facilities, light industrial development, market, etc. and prohibits uses like major commercial premises, animal husbandry, cemetery or crematorium, etc. The other basic facilities that are provided in this zone are education (14\%), recreation $(15 \%)$, health care $(3 \%)$, religious purpose $(3 \%)$, shops $(3 \%)$, and other facilities (1\%) (Figures $11 \& 12$ ).

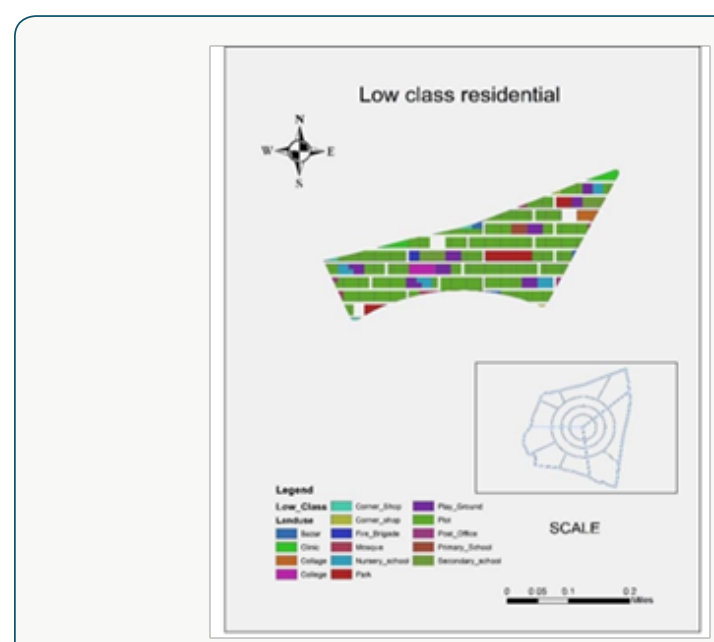

Figure 11: Design of Low class residential area in Proposed Town Center Development.

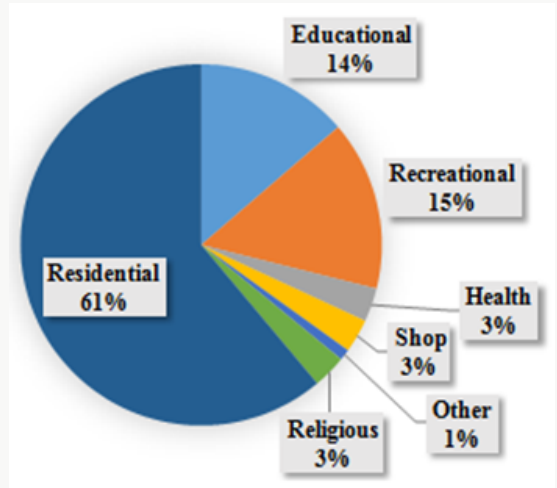

Figure 12: Percentage of land use distribution in proposed Low Class Residential area.

\section{Design description of civic zone}

Land included in community services zone is intended to accommodate public services such as educational, culture and religions facilities and government use not included in a Government Business Zone. Other uses included in a community services zone are institutional facilities such as prisons, etc. Land included in this Zone is intended for use for emergency services facilities, hospitals and other such facilities. A Horticulture center is provided in this zone as there is a huge amount of land where vegetable are cultivated. This zone permits uses like cultural facilities, educational facilities, religious facilities, exhibition and display facilities, conference and sports facilities, institutional facilities, emergency services facilities, civil emergency facilities, hospital, fire station, ambulance station, etc. and prohibits uses like industrial development, major commercial development, hotel, etc (Figure 13 \& 14).
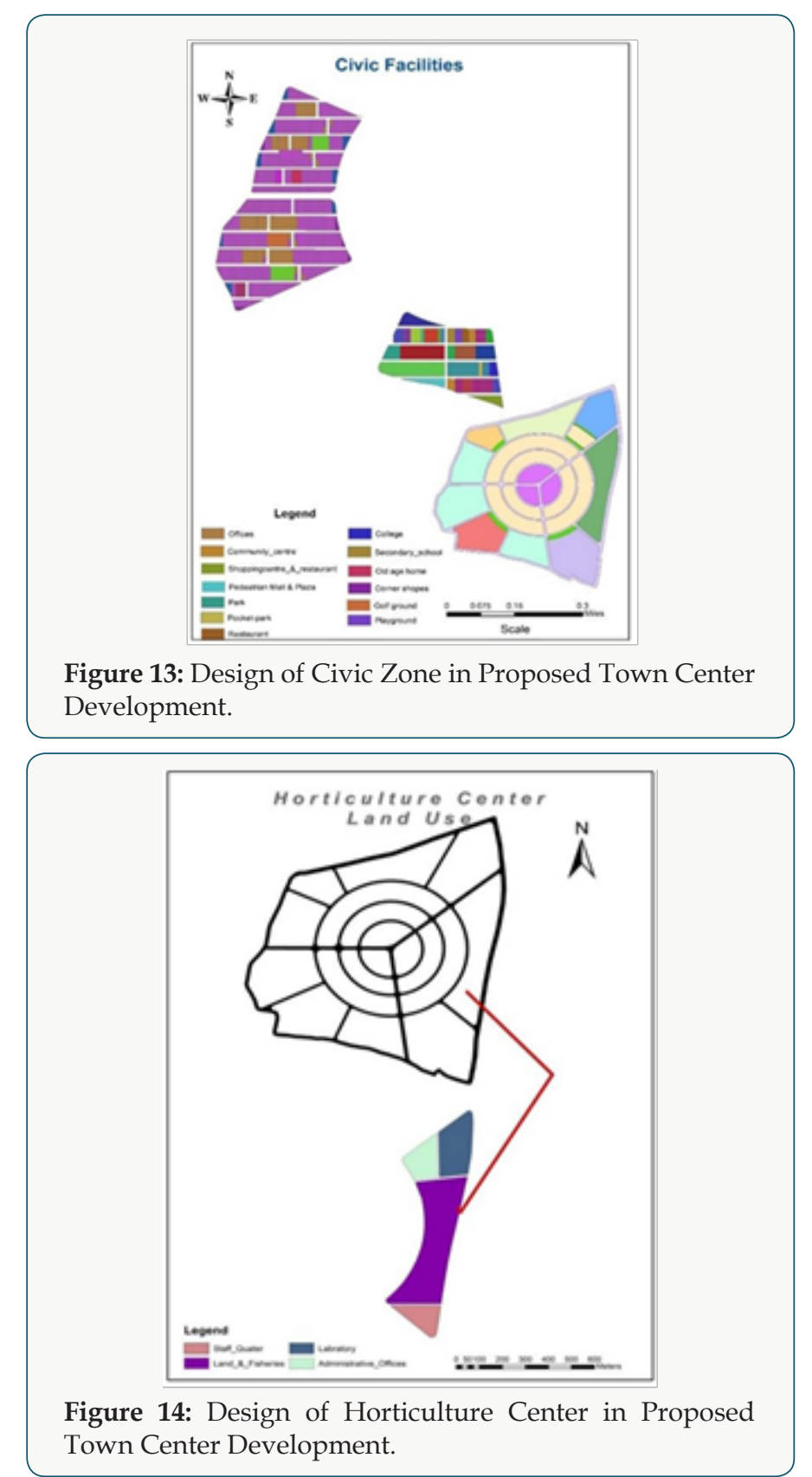

\section{Design description of mixed use zone}

Land in a Mixed Business Zone is intended for lower intensity commercial business development and retail display on the fringe of the Core area and adjacent to major arterial roads. Development will be predominantly free standing with adequate provision for car parking and access. Professional offices, medical clinics and surgeries, services, will generally be located in this zone. Major manufacturing and repair business will be excluded from the zone, and residential development will be confined to above ground floor of commercial premises. Special provisions will apply to traffic management to ensure pedestrian safety, and minimize congestion (Figures $15 \& 16$ ). The mixed use zone combines a number of uses. The land use distribution in this zone is; $71 \%$ residential, $4 \%$ educational, $4 \%$ administrative, $3 \%$ recreational, 
$3 \%$ religious, $3 \%$ health facility and $12 \%$ other facilities. The other facilities include uses like fruit shop, laundry, saloon, shopping center, market, wholesale, atm booth, cold storage, corner shop, fire brigade, milk dairies, biscuit factory, bazar, graveyard, etc.

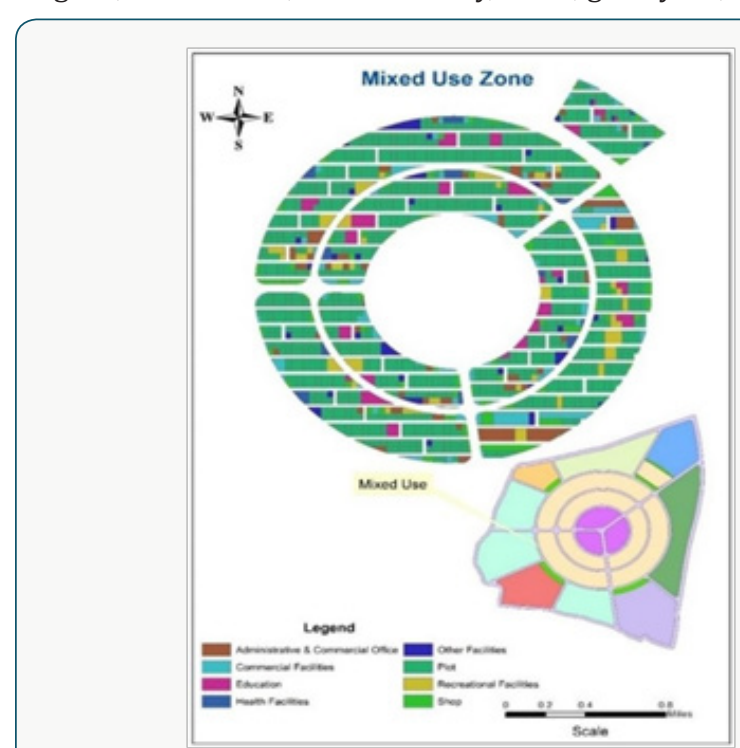

Figure 15: Design of Mixed use zone in Proposed Town Center Development.

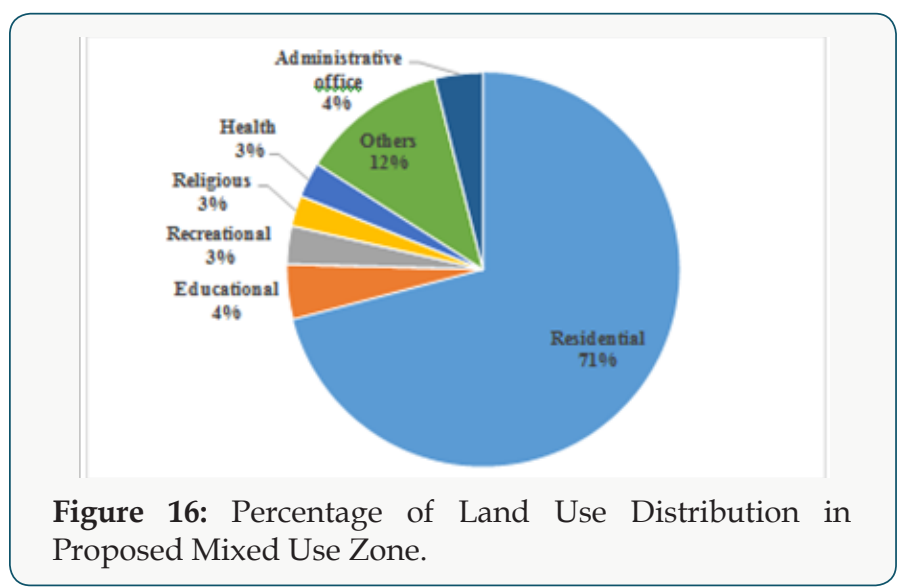

\section{Design description of industrial zone}

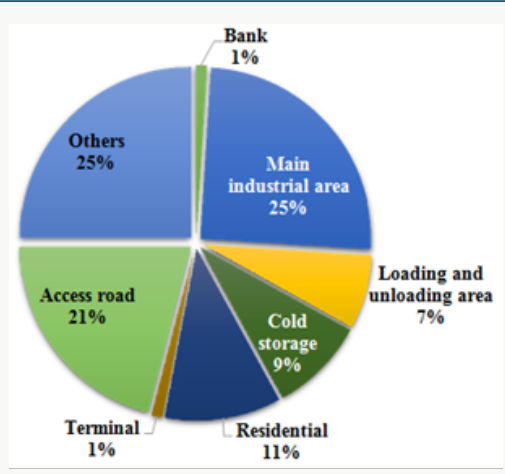

Figure 17: Percentage of Land Use Distribution in Proposed Industrial Zone.

Industrial Zone is divided into two categories, Heavy Industrial Zone \& Light Industrial Zone. This zone incorporates area to locate industries (25\%), area for loading and unloading (7\%), cold storage (9\%), bank (1\%), terminal (1\%), access road (21\%), residential area $(11 \%)$ and also land for other uses $(25 \%)$ which are essential to run the industries (Figure 17).

Heavy industrial zone: Land included in a Heavy Industrial zone is intended to accommodate a wide a range of industrial and related development including manufacturing, food processing, assembly of machinery, and heavy equipment, vehicles and appliances. Heavy industrial zones are located in strategic locations close to major roads and infrastructure to ensure that services are provided to a high standard and reliability. A limited range of retail, commercial office and warehousing will be permitted in the zone. Access and mobility will be strictly controlled to ensure traffic safety. Parking is provided in accordance with parking standards for the zone. Landscaping will be required along the frontage and adjacent to any development abutting a public open space area. This zone occupies total 29.24 acres area to serve approximately 2300 population. Uses like service industry, vehicle repair, transport yard, warehousing if not in excess of $50 \%$ of gross floor area, motor trading, utility service station, medical facilities for emergency services, canteens, food stalls, limited commercial retail, staff quarters, etc. are permitted and uses like transportation uses, institutional premises, animal husbandry, major commercial, educational facilities, child care centers, institutional premises are prohibited in this zone (Figure 18).

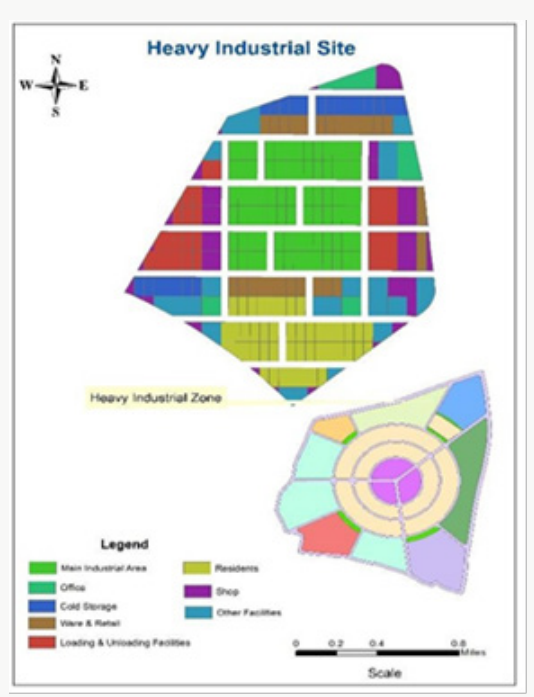

Figure 18: Design of Heavy industrial zone in Proposed Town Center Development.

Light industrial zone: Land in a Light Industrial Zone is intended for light industrial activities, particularly those using clean, low technologies to restrict air and noise offence. The sorts of industries that may be found in a light industrial zone might include those producing high value but low weight and volume goods, such as specialized electronic firms, IT based industries, jewelry, medical products, etc. This zone includes total 13.4 acres area and accommodates approximately 1200 population. This zone permits uses like low polluting industries, service industries, clinics, 
ancillary shop, childcare center, car park, limited transportation, small scale commercial outlets, canteens, mini parks and small recreation areas, etc. and uses like, major transportation uses, institutional premises, animal husbandry, major commercial, etc. are prohibited (Figure 19).

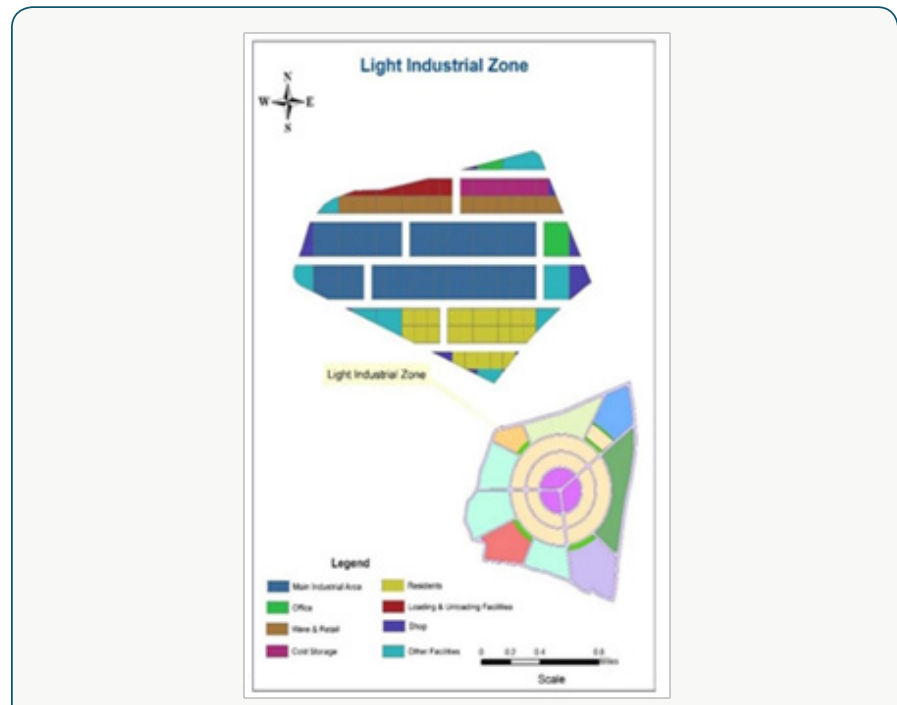

Figure 19: Design of Light industrial zone in Proposed Town Center Development.

\section{Conclusion}

The study has identified the need to relate growth targets to the appropriate provision of public transport, public open space and desirable built form outcomes, to create a sustainable and efficient Town Centre with high levels of amenity. This development plan is intended to guide the future growth of Shilinda Town Centre Precinct. The Development plan addresses the provision of transport measures, public open space and desirable built form on the basis of Rajshahi Metropolitan Development Plan (2004- 2024). The information and concepts presented in the Development plan are intended to guide on public and private use of land within the Town Centre Precinct as well as the provision of public facilities such as improvements to infrastructure, roads, public open space, etc. New streets, parks and pedestrian connections are designed in the development plan to provide suitable access and amenity to new, relatively fine grained urban blocks. The future urban form of the Shilinda Town Centre Precinct is balanced, connected, sustainable and cohesive, to strengthen the role of the Town Centre Precinct within the Rajshahi City. At the same time this study can be a mentionable example of a sustainable town center to be replicated. The study suggests such a town center design which is easy to manage and will sustain with its own internal functionality.

\section{References}

1. Coca Stefaniak (2013) A Successful Town Centres-Developing Effective Strategies.

2. Mahbub Un Nabi ASM (2012) Urban Planning Principles.

3. (2011) Sherborn Town Center: at a Crossroads.

4. Prothan JIJ, Islam M, Rahman A, Pramanik A (2017) Transportation System Analysis at the Major Road Intersection in the CBD Area of Rangpur City, Bangladesh. International Journal of Transportation Engineering and Technology 3(4): 74-82.

5. Bennison D J, Davies R L (1980) The impact of town centre shopping schemes in Britain: Their impact on taditional retail environments. Progress in Planning, 14(3): 1-104.

6. McGoldrick PJ, Thompson MG (1992) The role of image in the attraction of the out-of-town centre. The International Review of Retail, Distribution and Consumer Research 2(1): 81-98.

7. Beyard MD, Kramer A, Leonard B, Pawlukiewicz M, Schwanke D, et al. (2007) Ten Principles for Developing Successful Town Centers. Urban Land Institute, Washington, USA.

8. Page SJ, Hardyman R (1996) Place Marketing and Town Centre management: A New Tool for Urban Revitalization. Elsevier Science Ltd 13(3): 153-164.

9. Woolley H (2000) Town centre management awareness: an aid to developing young people's citizenship. Cities 17(6): 453-459.

10. Whyatt G (2004) Town centre management: how theory informs a strategic approach 32(7): 346-353.

11. Gayler HJ (1984) Retail innovation in Britain: the problems of out-oftown shopping centre development: Geo Books.

12. Gibberd F (1970) Town design: architectural Press. International Journal of Retail \& Distribution Management 32(7): 46-353.

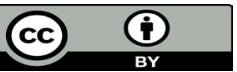

This work is licensed under Creative Commons Attribution 4.0 License

To Submit Your Article Click Here:

Submit Article

DOI: 10.32474/TCEIA.2018.02.000141

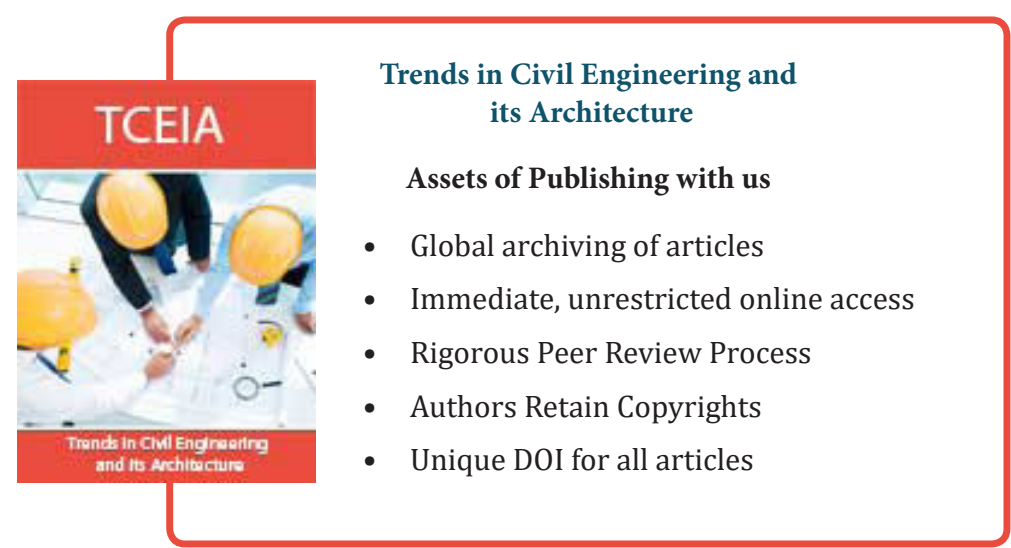

